\title{
Joint production of IL-22 participates in the initial phase of antigen-induced arthritis through IL-1 $\beta$ production
}

Larissa G. Pinto ${ }^{1}$, Jhimmy Talbot ${ }^{1}$, Raphael S. Peres ${ }^{1}$, Rafael F. Franca ${ }^{1,4}$, Sérgio H. Ferreira', Bernhard Ryffel ${ }^{2}$, José Carlos F. Aves-Filho ${ }^{1}$, Florêncio Figueiredo ${ }^{3}$, Thiago M. Cunha ${ }^{1 *}$ and Fernando Q. Cunha ${ }^{1 *}$

\begin{abstract}
Introduction: Rheumatoid arthritis (RA) is a chronic autoimmune disease characterized by neutrophil articular infiltration, joint pain and the progressive destruction of cartilage and bone. IL-22 is a key effector molecule that plays a critical role in autoimmune diseases. However, the function of IL-22 in the pathogenesis of RA remains controversial. In this study, we investigated the role of IL-22 in the early phase of antigen-induced arthritis (AIA) in mice.

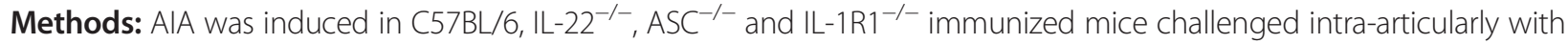
methylated bovine serum albumin (mBSA). Expression of IL-22 in synovial membranes was determined by RT-PCR. Articular hypernociception was evaluated using an electronic von Frey. Neutrophil recruitment and histopathological analyses were assessed in inflamed knee joint. Joint levels of inflammatory mediators and mBSA-specific IgG concentration in the serum were measured by ELISA.
\end{abstract}

Results: The IL-22 mRNA expression and protein levels in synovial tissue were increased during the onset of AIA. In addition, pharmacological inhibition (anti-IL-22 antibody) and genetic deficiency (IL-22 ${ }^{-1-}$ mice) reduced articular pain and neutrophil migration in arthritic mice. Consistent with these findings, recombinant IL-22 joint administration promoted articular inflammation per se in WT mice, restoring joint nociception and neutrophil infiltration in IL-22 $2^{-1-}$ mice. Moreover, IL-22-deficient mice showed reduced synovitis (inflammatory cell influx) and lower joint IL-1 $\beta$ levels, whereas the production of IL-17, MCP-1/CCL2, and KC/CXCL1 and the humoral immune response were similar, compared with WT mice. Corroborating these results, the exogenous administration of IL-22 into the joints induced IL-1 $\beta$ production in WT mice and reestablished IL-1 $\beta$ production in IL-22 ${ }^{-/-}$mice challenged with mBSA. Additionally, IL-1R1 ${ }^{-1-}$ mice showed attenuated inflammatory features induced by mBSA or IL-22 challenge. Articular nociception and neutrophil migration induced by $\mathrm{IL}-22$ were also reduced in $\mathrm{ASC}^{-/-}$mice.

Conclusions: These results suggest that IL-22 plays a pro-inflammatory/pathogenic role in the onset of AIA through an ASC-dependent stimulation of IL-1 $\beta$ production.

\section{Introduction}

Rheumatoid arthritis (RA) is a chronic autoimmune disorder that is characterized by symmetric inflammation of the joints, which leads to the progressive destruction of cartilage and bone [1]. The underlying cause of RA is unknown; however, it is mediated by the persistent production of pro-inflammatory cytokines, matrix

\footnotetext{
* Correspondence: thicunha@usp.br; fdqcunha@fmrp.usp.br

'Department of Pharmacology, Ribeirão Preto Medical School, University of São Paulo, Avenida Bandeirantes, 3900, Ribeirão Preto, São Paulo 14049-900, Brazil

Full list of author information is available at the end of the article
}

metalloproteinases (MMPs) and others mediators, all of which play a key role in triggering synovial cell activation that leads to joint destruction and, consequently, articular pain $[2,3]$.

Pro-inflammatory cytokines, including tumor necrosis factor (TNF)- $\alpha$, interleukin (IL)-1 $\beta$, IL-6 and, more recently, IL-17, play a crucial role in the pathogenesis of arthritis, increasing the recruitment of neutrophils into the joint and driving the enhancement of chemokines and degradative enzymes production $[4,5]$. In addition, several groups, including ours, have demonstrated the participation of these cytokines in the development of articular 
pain, which can act directly or indirectly on nociceptive neurons inducing their sensitization [6-10]. Although the pathogenic effects of these cytokines are well explored, the contribution of IL-22 in this context is not yet fully understood.

IL-22 is an IL-10 family cytokine member produced by several different cell types, including $\mathrm{T}$ helper (Th)17 cells, natural killer (NK) cells, $\gamma \delta$ T cells, Th22 cells and lymphoid tissue inducer-like cells (LTi) [11, 12]. IL-22 acts through a transmembrane receptor complex (IL-22R) comprising the IL-22R1 and IL-10R2 subunits [13, 14]. This heterodimeric receptor is expressed in resident tissue cells and is not expressed by hematopoietic immune cells $[15,16]$. Interestingly, because immune cells do not express IL-22R1, IL-22 does not directly regulate the functions of these cells. This fact discriminates IL-22 from the majority of conventional cytokines, which directly act on hematopoietic cells. Of note, a few types of tissue cells express the IL-22R1 chain such as cells of the skin, kidney, and liver, those from the respiratory and digestive system, and those of the joints (synovial fibroblasts), whereas the IL-10R2 subunit is ubiquitously expressed [15]. Thus, the expression of the IL-22R1 chain determines whether a cell is an IL-22 target $[15,17]$. IL-22 has many functions such as regulating inflammation and autoimmunity [18-21]. Several studies indicated that IL-22 production is increased during autoimmune diseases, including rheumatoid arthritis [22, 23]. However, the role of this cytokine in the onset of these diseases remains controversial. On the one hand, there is evidence that IL-22 expression in synovial tissue is increased in patients with RA and that its upregulation often correlates with disease activity [24,25]. Moreover, in experimental models of arthritis, IL-22 $2^{-/}$ mice were less susceptible to collagen-induced arthritis (CIA) [26]. On the other hand, there is evidence that IL-22 has an anti-inflammatory effect during CIA through an increased IL-10 response, indicating that IL-22 would have dual effects depending on the phase of the disease [27]. Taking into account these apparent contradictions in the present study, we investigated the contribution of IL-22 and the mechanism underlying the pathogenesis of joint inflammation during the acute phase of antigen-induced arthritis (AIA).

\section{Methods}

\section{Animals}

The experiments were performed using male C57BL/6 wild-type (WT) mice and IL-22, IL-1R1, apoptosisassociated speck-like protein containing a C-terminal caspase recruitment domain (ASC) and Toll-like receptor 4 (TLR4) (all in C57BL/6 background) deficient ${ }^{(-)}$mice weighing $20-25$ g. All knockout mice used in this study were co-housed with WT mice for 2 weeks prior to immunization and throughout the period of arthritis induction. IL-22 $2^{-/-}$mice did not present any sign of other phenotypes (such as gut diseases) for the duration of the study. The mice were housed in temperature-controlled rooms $\left(22-25^{\circ} \mathrm{C}\right)$ and given water and food ad libitum at the animal facility in the Department of Pharmacology, Ribeirão Preto Medical School, University of São Paulo, Brazil. The mice were taken to the testing room at least 1 $\mathrm{h}$ before experiments and were used once. All experiments were conducted in accordance with the prescribed guidelines on experimental animal welfare of the National Institutes of Health and were approved by the Ethics Committee of the Ribeirão Preto Medical School, University of São Paulo.

\section{Drugs}

The following materials were obtained from the indicated sources: recombinant murine IL-22 (rmIL-22; R\&D Systems, Minneapolis, MN, USA), anti-IL-22 antibody ( $\alpha$-IL-22) (16-7222-85; eBioscience, San Diego, CA, USA), zymosan, fucoidin, methylated bovine serum albumin (mBSA) and complete Freund adjuvant (CFA; Sigma-Aldrich, St. Louis, MO, USA). The drugs were diluted in sterile saline.

\section{Induction of experimental arthritis \\ Antigen-induced arthritis (AIA)}

The mice were immunized as previously described [28]. Briefly, the mice were sensitized with $500 \mu \mathrm{g}$ of mBSA in $0.2 \mathrm{ml}$ of an emulsion containing $0.1 \mathrm{ml}$ saline and 0.1

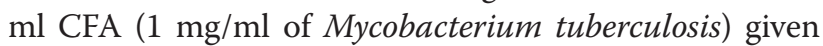
by subcutaneous (s.c.) injection on day 0 . The mice were boosted with the same preparation on day 7. Shamimmunized (SI) mice were given similar injections but without the antigen (mBSA). Twenty-one days after the initial injection, arthritis was induced in the immunized animals by an intra-articular (i.a.) injection of mBSA (30 $\mu \mathrm{g} /$ joint) or IL-22 (0.1, 0.3, 1 or $3 \mathrm{ng} /$ joint) dissolved in $10 \mu \mathrm{L}$ of saline into the right femur-tibial joint. It is important to mention that previous reports demonstrated that the administration of mBSA in SI mice induced effects similar to those produced by the injection of saline, indicating that, in immunized mice, mBSA induced a specific immune response, thus excluding the possibility of any contamination $[9,29]$.

\section{Zymosan-induced arthritis (ZIA)}

ZIA was induced using a previously described protocol [30]. In brief, joint inflammation was induced by the i.a. administration of $30 \mu \mathrm{g}$ of zymosan (from Saccharomyces cerevisiae) that was diluted in $10 \mu \mathrm{L}$ of saline into the right femur-tibial joint. Control mice were injected with $10 \mu \mathrm{L}$ of saline into the same joint. 


\section{Evaluation of articular hypernociception}

The articular hypernociception of the femur-tibial joint was evaluated using a previously described method [9]. In a quiet room, the mice were placed in acrylic cages $(12 \times 10 \times 17 \mathrm{~cm}$ high $)$ with a wire grid floor $15-30 \mathrm{~min}$ before testing for environmental adaptation. Stimulations were performed only when the animals were quiet, did not display exploratory movements or defecation and were not resting on their paws. In these experiments, an electronic pressure meter, which comprises a hand-held force transducer fitted with a polypropylene tip (IITC Inc., Life Science Instruments, Woodland Hills, CA, USA), was used. For this model, a large tip $\left(4.15 \mathrm{~mm}^{2}\right)$ was adapted to the probe. The investigator (blind to group allocation) was trained to apply the tip perpendicularly to the central area of the plantar surface of the hind paw to induce flexion of the femur-tibial joint, followed by paw withdrawal. A gradual increase in pressure was manually performed in blind experiments. The upper limit pressure was $15 \mathrm{~g}$. The electronic pressure meter apparatus automatically recorded the intensity of the force applied when the paw was withdrawn. The test was repeated until three subsequent consistent measurements (i.e., the variation among these measurements was less than $1 \mathrm{~g}$ ) were obtained. The flexion-elicited mechanical threshold was expressed in grams (g).

\section{In vivo neutrophil migration}

Immunized or non-immunized mice were challenged with mBSA, IL-22, zymosan or saline directly into the articular cavity. At various time points after injection of the inflammatory stimuli, the mice were sacrificed. The articular cavities were washed twice with $5 \mu \mathrm{L}$ phosphate-buffered saline (PBS) containing $1 \mathrm{mM}$ ethylenediaminetetraacetic acid (EDTA) and were then diluted to a final volume of $50 \mu \mathrm{L}$ with PBS/EDTA to evaluate leukocyte migration at the indicated times. The total number of leukocytes was counted in a Neubauer chamber diluted in Turk's solution. Differential cell counts were determined in cytocentrifuge Rosenfeld-stained slices (Cytospin 4; Shandon, Pittsburgh, PA, USA). Differential cell counts were performed with a light microscope, and the results were expressed as the number (mean \pm SEM) of neutrophils per joint cavity.

\section{Cytokine measurements}

At the indicated times after i.a. injection of the inflammatory stimuli, the animals were terminally anesthetized, and the knee joints or synovial membranes were removed and homogenized in $500 \mu \mathrm{l}$ or $100 \mu \mathrm{l}$, respectively, of buffer-containing protease inhibitors. IL-17, IL-1 $\beta$, IL-22, monocyte chemoattractant protein-1 (MCP-1/CCL2) and keratinocyte-derived chemokine (KC/CXCL1) concentrations were measured by enzyme-linked immunosorbent assay (ELISA) using commercial kits (DuoSet; R\&D Systems) as previously described [31]. The results are expressed as pg/joint of each cytokine. As a control, the concentrations of these cytokines were measured in immunized animals injected with saline and in SI mice injected with mBSA.

\section{Pharmacological treatments}

In this study the following pharmacological treatments were used: (i) C57BL/6 immunized mice were co-treated with an antibody against IL-22 ( $\alpha$-IL-22, $5 \mu \mathrm{g} /$ joint) or control isotype antibody ( $\alpha$-CTL, $5 \mu \mathrm{g} /$ joint), which was administered simultaneously with mBSA (30 $\mu \mathrm{g} /$ joint) or saline $(10 \mu \mathrm{l})$ into the right femur-tibial joint, and mechanical articular hypernociception was evaluated 1-7 h after administration of the stimulus, followed by the evaluation of neutrophil migration. (ii) WT or IL- $22^{-/-}$immunized mice were challenged i.a. with saline or mBSA $(30 \mu \mathrm{g} /$ joint) and co-treated with a co-injection of rmIL-22 (0.3 ng/joint) or vehicle, and articular hypernociception and neutrophil migration were evaluated $7 \mathrm{~h}$ following the challenge. In another set of experiments, mBSAimmunized WT or IL-22 $2^{-1-}$ mice were injected i.a. with mBSA $(30 \mu \mathrm{g})$ or saline and co-treated with a co-injection of IL-22 (0.3 ng) or vehicle. The concentrations of IL-1 $\beta$ were determined $3 \mathrm{~h}$ after the challenge. (iii) mBSAimmunized mice were pretreated with fucoidin, a leukocyte adhesion inhibitor $(20 \mathrm{mg} / \mathrm{kg}$, i.v. $15 \mathrm{~min}$ prior to the i.a. injection of IL-22), and levels of IL-1 $\beta$ in the joint were determined by ELISA $3 \mathrm{~h}$ after the injection of rmIL-22.

\section{Anti-mBSA antibody titer measurement}

Serum anti-mBSA antibody titers in pooled sera from WT and IL-22 $2^{-/}$mice were measured by ELISA. In brief, 96-well plates were coated with $50 \mu \mathrm{lmBSA}$ solution $\left(10 \mu \mathrm{g} / \mathrm{ml}\right.$, in $0.1 \mathrm{M}$ phosphate buffer) overnight at $4{ }^{\circ} \mathrm{C}$. After that, serial dilutions of sera were added and incubated overnight at $4{ }^{\circ} \mathrm{C}$. Bound total immunoglobulin (Ig)G and IgG2a were detected with biotin-conjugated anti-mouse IgG and anti-mouse IgG2a, respectively (Vector Laboratories, Burlingame, CA, USA). Finally, $50 \mu \mathrm{l}$ avidin-HRP (1:5000 dilution; Dako, Glostrup, Denmark) was added to each well, and after $30 \mathrm{~min}$, the plates were washed, and the color reagent OPD $(200 \mu \mathrm{g} / \mathrm{well}$; SigmaAldrich) was added. After $15 \mathrm{~min}$, the reaction was stopped with $1 \mathrm{M} \mathrm{H}_{2} \mathrm{SO}_{4}$ and the OD was read at $490 \mathrm{~nm}$.

\section{Reverse transcription-polymerase chain reaction (RT-PCR) assays}

IL-22 mRNA expression was measured by RT-PCR as previously described [9]. Briefly, mice were sacrificed $3 \mathrm{~h}$ after mBSA injections (i.a.), and the synovial membranes were harvested. Total cellular RNA from synovial membranes was extracted using the TRIzol reagent 
(Invitrogen Life Technologies Corp., Carlsbad, CA, USA) according to the directions supplied by the manufacturer. The purity of the total RNA was measured with a NanoVue Plus spectrophotometer (GE Healthcare, Little Chalfont, UK). The wavelength absorption ratio (260/280 $\mathrm{nm}$ ) was between 1.8 and 2.0 for all preparations. cDNA was produced from total RNA by reverse transcription (Superscript II, Gibco Life Technologies, Grand Island, NY, USA). Real-time quantitative PCR mRNA analysis was performed on an ABI Prism 7500 Sequence Detection System using the SYBR-green fluorescence system (Applied Biosystems, Warrington, UK) for the quantification of amplicons. RT-PCR was performed in a $13-\mu \mathrm{L}$ reaction volume and carried out with the following cycling parameters: initial heating at $95{ }^{\circ} \mathrm{C}(10 \mathrm{~min})$, followed by 40 cycles of $94{ }^{\circ} \mathrm{C}(1 \mathrm{~min}), 56{ }^{\circ} \mathrm{C}(1 \mathrm{~min})$ and $72{ }^{\circ} \mathrm{C}(2 \mathrm{~min})$. Melting curve analysis was performed $\left(65-95{ }^{\circ} \mathrm{C}\right)$ to verify the amplification of a single product. Samples with more than one peak were excluded. The data were analyzed according to the comparative cycle threshold (CT) method. The primer pairs for mouse glyceraldehyde 3-phosphate dehydrogenase (GAPDH) and IL-22 were as follows:

IL-22 forward: 5'- AGC AAA TCA GCT CAG CTC CTG- 3';

IL-22 reverse: $5^{\prime}-$ CTT CTT CTC GCT CAG ACG CA- 3';

GAPDH forward: 5'- CAT CTT CTT GTG CAG TGC CA -3';

GAPDH reverse: 5'- CGG CCA AAT CCG TTC AC-3';

\section{Histological analysis}

Femur-tibial joints were collected $7 \mathrm{~h}$ after challenge with mBSA, fixed in $10 \%$ (vol/vol) buffered formalin and decalcified in a solution of sodium citrate and formic acid for 2-3 weeks. The tissues were then trimmed, dehydrated in graded ethanol, embedded in paraffin, cut into 5- $\mu \mathrm{m}$ thick frontal sections and stained with hematoxylin and eosin (H\&E). Two independent observers that were blinded to the treatment graded the extent of synovitis (inflammatory cell influx and synovial hyperplasia). The histological scoring system used was as follows: none (0), mild (1), moderate (2) or severe (3) synovitis.

\section{Statistical analysis}

Data are reported as the means \pm SEM and are representative of two separate experiments. Two-way ANOVA was used to compare the groups and doses at the different times (curves) when the hypernociceptive responses were measured after the stimulus injection. The analyzed factors were the treatments, the time, and the time versus treatment interaction. If there was a significant time versus treatment interaction, one-way ANOVA followed by
Bonferroni's $t$ test was performed for each time. Alternatively, if the responses (hypernociception, neutrophil migration, and cytokine production) were measured only once after the stimulus injection, the differences between responses were evaluated by one-way ANOVA followed by Bonferroni's $t$ test (for three or more groups), comparing all pairs of columns, or by two-tailed Student's $t$ test (for two groups). $P$ values less than 0.05 were considered significant. Statistical analysis was performed with GraphPad Prism (GraphPad Software, San Diego, CA, USA).

\section{Results}

Local production of IL-22 participates in the pathogenesis of AIA in mice

First, it was observed that the mBSA challenge into the femur-tibial joint of immunized mice induced an increase in IL-22 mRNA expression in synovial tissue $3 \mathrm{~h}$ after stimulus injection (Fig. 1a). Additionally, the i.a. injection of mBSA in immunized mice also promoted an increase in IL-22 protein levels in the synovial membrane at $7 \mathrm{~h}$ after the challenge (Fig. 1b). Local (joint) treatment of mice with a neutralizing antibody against IL-22 (injected simultaneously with mBSA) reduced joint nociception and neutrophil migration during arthritis development (Fig. 1c and d).

The local pro-inflammatory effect of IL-22 in AIA was further confirmed because a rmIL-22 challenge into the femur-tibial joint in mBSA-immunized mice induced a dose- and time-dependent decrease in the mechanical nociceptive threshold (Fig. 1e) and stimulation of neutrophil recruitment at $7 \mathrm{~h}$ after the challenge (Fig. 1f). A significant articular nociceptive response was observed $1 \mathrm{~h}$ after i.a. injections of IL-22 at all doses (0.1-3 ng), which progressively increased for $7 \mathrm{~h}$ following the challenge (Fig. 1e). An i.a. injection of IL-22 induced a significant dose-dependent (0.1-3 ng/joint) decrease in the nociceptive threshold (Fig. 1e) and an increase of neutrophil migration (Fig. 1f) when compared to mice that were injected with saline. A dose of $1 \mathrm{ng}$ per joint of IL-22 produced a significant difference in articular pain and neutrophil recruitment compared with doses of 0.1 and $0.3 \mathrm{ng}$ of IL-22. A dose of $3 \mathrm{ng} /$ joint produced no further effects (Fig. 1e and f). Consequently, a dose of $1 \mathrm{ng}$ per joint of IL-22 was used in subsequent experiments. The effects of IL-22 were reduced in SI mice when compared with mBSA-immunized mice (data not shown). In an attempt to exclude possible contamination with lipopolysaccharide (LPS) in the IL-22 preparations, IL-22 was administered into the joints of TLR $4^{-/-}$mice, and articular hypernociception and neutrophil migration were determined. It was observed that IL-22-induced articular hypernociception and neutrophil migration were similar in TLR4 ${ }^{-1-}$ mice when compared with WT mice (Figure S1A and S1B in Additional file 1). 

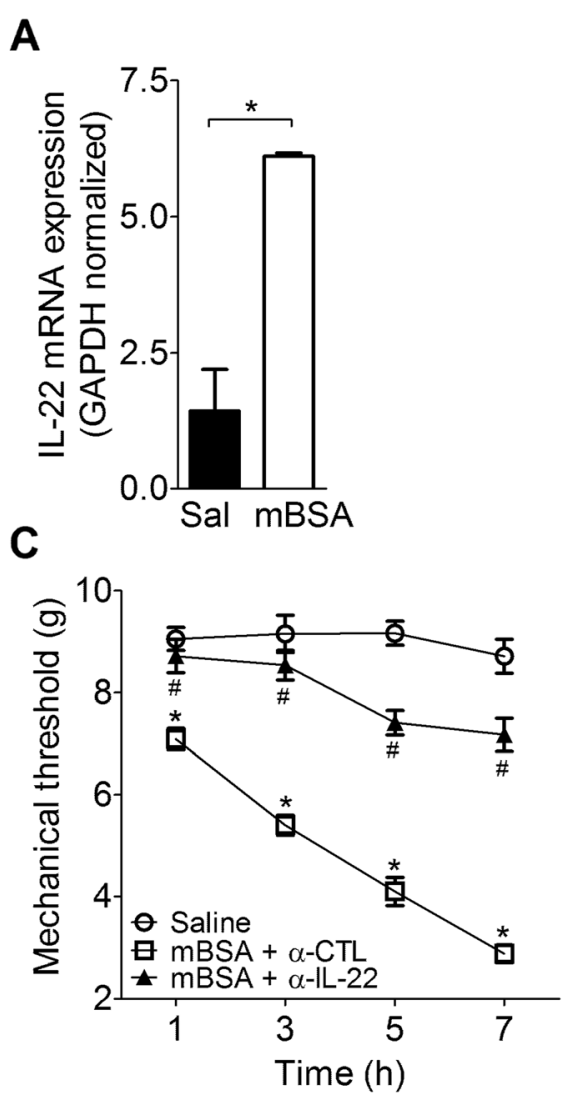

E

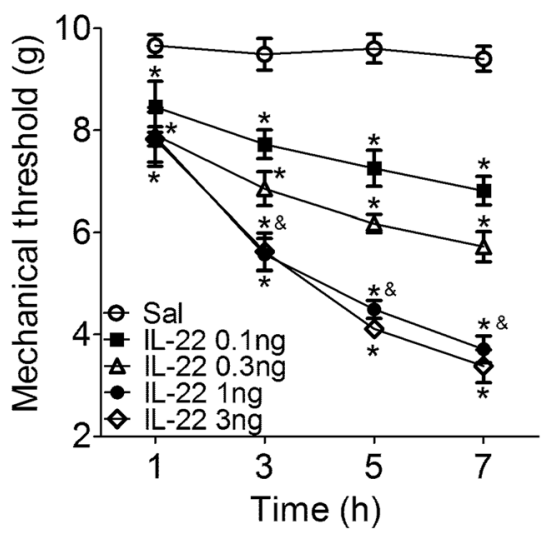

B
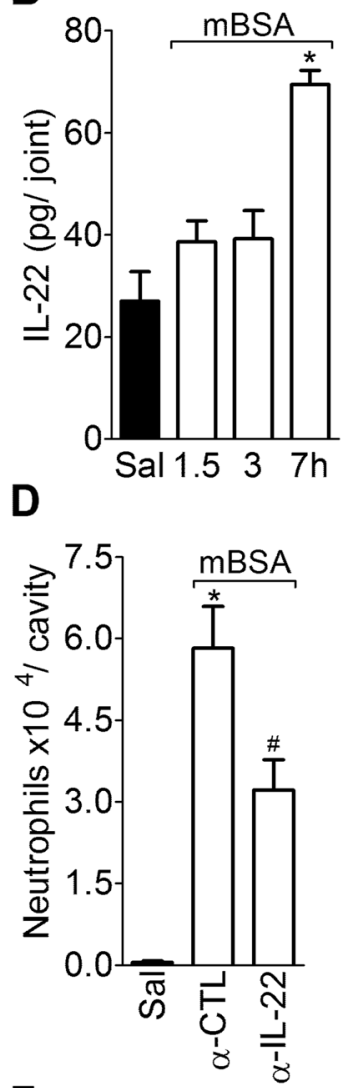

$\mathbf{F}$

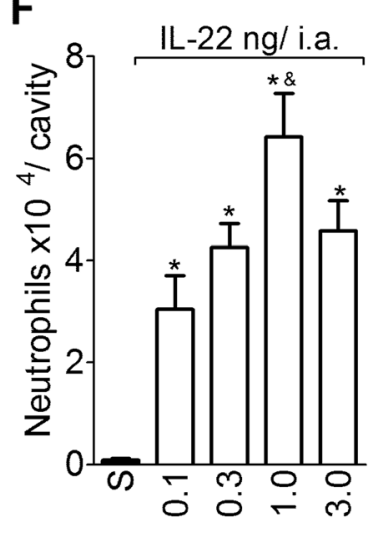

Fig. 1 Role of IL-22 in the acute phase of AIA. a mBSA-immunized mice were challenged i.a. with $30 \mu \mathrm{g}$ of mBSA or saline. After $3 \mathrm{~h}$, synovial membranes were collected and analyzed for IL-22 mRNA expression by PCR. The gene expression was normalized to GAPDH expression. $\mathbf{b}$ The concentrations of $\mathrm{IL}-22$ in the synovial membranes were determined at 1.5, 3 and $7 \mathrm{~h}$ after a challenge with either $30 \mu \mathrm{g}$ of $\mathrm{mBSA}$ or saline in mBSA-immunized mice. c Articular hypernociception was evaluated 1-7 h after i.a. injection with either mBSA (30 $\mu \mathrm{g}$ ) or saline in mBSA-immunized mice treated with a co-injection of IgG control ( $\mathrm{a}-\mathrm{CTL})$ or a-IL-22 $(5 \mu \mathrm{g} /$ cavity) antibodies. $\mathbf{d}$ Neutrophil recruitment from the articular cavity $7 \mathrm{~h}$ after i.a. administration of $\mathrm{mBSA}(30 \mathrm{\mu g})$ or saline and treatment with a co-injection of a-CTL or a-lL-22 antibodies. e and $\mathbf{f}$ mBSA-immunized mice were challenged i.a. with either $0.1-3 \mathrm{ng}$ of $\mathrm{rm} / \mathrm{L}-22$ or $10 \mu \mathrm{l}$ of saline. e Articular hypernociception was evaluated over a period of $7 \mathrm{~h}$. $\mathbf{f}$ Neutrophil recruitment from the articular cavity $7 \mathrm{~h}$ after i.a. injection of either IL-22 (0.1-3 ng per joint) or saline in mBSA-immunized mice. Data are the means $\pm \operatorname{SEM}(n=5)$. ${ }^{*} P<0.05$, compared with the saline group; ${ }^{\#} P<0.05$, compared with the mBSA plus a-CTL group; and ${ }^{\&} P<0.05$, compared with the IL-22 0.1 and 0.3 ng i.a. groups. AIA antigen-induced arthritis, GAPDH glyceraldehyde 3-phosphate dehydrogenase, i.a. intra-articular, $1 \mathrm{~g}$ immunoglobulin, IL interleukin, mBSA methylated bovine serum albumin, PCR polymerase chain reaction, rmIL-22 recombinant murine IL-22 
To further confirm the participation of IL-22 in the pathophysiological mechanisms associated with AIA development, IL-22 $2^{-/-}$immunized mice were challenged with i.a injection of mBSA. On the one hand, corroborating with the pharmacological data, joint nociception and neutrophil migration were reduced in IL-22 $2^{-1-}$ compared with WT mice $7 \mathrm{~h}$ after mBSA challenge (Fig. $2 \mathrm{a}$ and $\mathrm{b}$ ). On the other hand, joint injections of exogenous rmIL-22 during the antigen challenge were able to reestablish articular hypernociception and neutrophil migration in IL-22 $2^{-/-}$ mice (Fig. 2a and b).

Further exploring the participation of IL-22 in the acute inflammatory response during AIA, the histopathological analyses of joint tissue revealed that IL- $22^{-/-}$mice showed reduced synovitis with less cellular infiltration and the absence of synovial hyperplasia and cartilage damage when compared with WT mice $7 \mathrm{~h}$ after mBSA challenge (Fig. 3a and b). Altogether, these results suggest that local IL-22 production is required for the acute joint inflammatory response during AIA in mice.

To verify whether the reduced local inflammatory response in IL-22 $2^{-1-}$ mice during AIA was due to an impaired immunization state, anti-mBSA antibody levels in the sera of immunized mice were determined. Interestingly, the serum levels of antibodies against mBSA, total IgG (Figure S2A in Additional file 2) and IgG2a (Figure S2B in Additional file 2) were similar in immunized WT and IL-22 $2^{-/-}$mice (Figure S2A and B in Additional file 2). Altogether, these findings suggest that the lower inflammatory response of IL-22 $2^{-/-}$mice during AIA was not associated with a decreased humoral immune response to mBSA.
Next, we developed a model of zymosan-induced arthritis in IL-22 $2^{-1-}$ mice to evaluate whether the reduction of AIA in IL-22 $2^{-/-}$mice is a specific phenotype or a consequence of strain manipulation. Injection of zymosan (i.a., $30 \mu \mathrm{g} /$ joint) induced mechanical articular hypernociception and intense neutrophil recruitment in WT mice that was not altered in IL-22 $2^{-1-}$ mice (Figure S3A and $\mathrm{B}$ in Additional file 3). These findings argue against IL-22 $2^{-1-}$ mice having a defect in the inflammatory response as a consequence of genetic manipulation.

\section{IL-22 mediates the acute inflammatory response of AIA through the modulation of IL-1 $\beta$ production}

To identify the possible underlying mechanisms by which IL-22 mediates the local inflammatory response during AIA, local cytokine and chemokine production was determined in the joints of IL-22 $2^{-/-}$mice. The injection of mBSA into the joints in WT immunized mice increased the local production of IL-1 $\beta$, IL-17, MCP-1/CCL2, and $\mathrm{KC} / \mathrm{CXCL} 1$ at $3 \mathrm{~h}$ after the challenge (Fig. $4 \mathrm{a}-\mathrm{d}$, respectively). Interestingly, the production of IL-1 $\beta$ (Fig. 4a) was reduced in $\mathrm{IL}-22^{-/}$mice during the early phase of AIA, whereas the production of IL-17, MCP-1/CCL2 and KC/CXCL1 did not differ from WT mice (Fig. 4b-d).

To confirm the participation of IL- $1 \beta$ in the inflammatory response during the early phase of AIA, IL-1R1-1mice were immunized, followed by i.a. injections of mBSA. First, mBSA challenge into the femur-tibial joint of WT mice produced a time-dependent increase in the levels of IL-1 $\beta$ in the joint tissues (Fig. 5a). Additionally, joint nociception and neutrophil migration during AIA were significantly diminished in $\mathrm{IL}-1 \mathrm{R} 1^{-/-}$mice after mBSA challenge
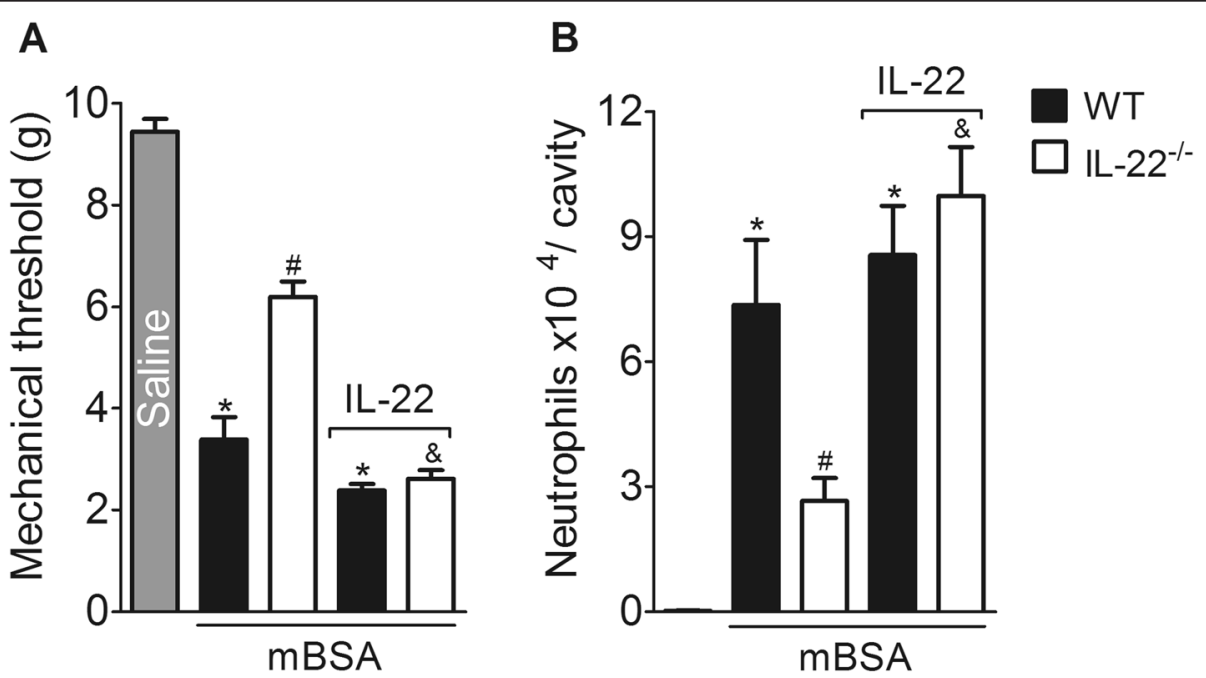

Fig. $2 \mathrm{IL}-22$ is required for articular hypernociception and neutrophil migration in AIA. mBSA-immunized wild-type (WT) mice or IL-22 ${ }^{-/-}$mice were challenged i.a. with saline or mBSA $(30 \mu \mathrm{g})$ and treated with a co-injection of rmlL-22 (0.3 ng) or vehicle. Articular hypernociception (a) and neutrophil migration (b) were evaluated $7 \mathrm{~h}$ following the challenge. Data are the means $\pm \operatorname{SEM}(n=5)$. ${ }^{*} P<0.05$, compared with the saline group; ${ }^{\#} P<0.05$, compared with the WT mBSA group; and ${ }^{\&} P<0.05$ compared with the $\mathrm{IL}-22^{-/-}$mBSA group. ${ }^{(-/-)}$deficient, AlA antigen-induced arthritis, i.a. intra-articular, IL interleukin, mBSA methylated bovine serum albumin, rm/L-22 recombinant murine IL-22 

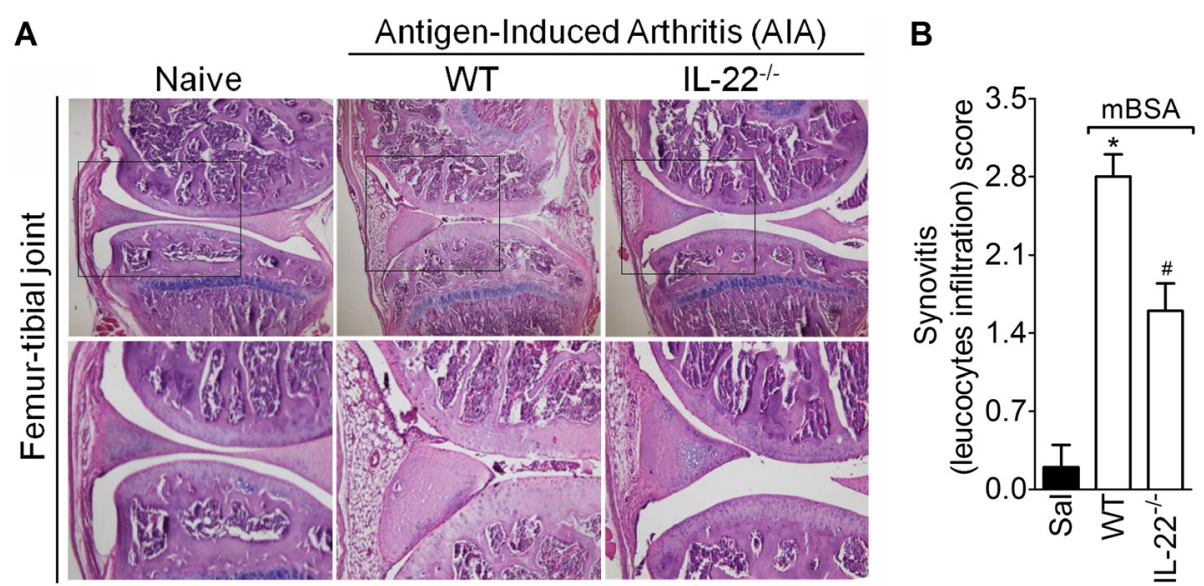

Fig. 3 Lower histopathological score in IL-22-deficient mice than in WT mice with AIA. Histological analysis of knee joints of WT and IL-22 ${ }^{-/-}$ immunized mice $7 \mathrm{~h}$ after mBSA (30 $\mathrm{\mu g}$ /i.a.) challenge. a Hematoxylin and eosin (H\&E)-stained representative histological section (upper panel: magnification, $5 x$; and lower panel: higher magnification, 20x). b AlA severity was measured by the histological score for synovitis. The histological scoring system used was as follows: none (0), mild (1), moderate (2) or severe (3) synovitis. Data represent the mean \pm SEM ( $n=6)$, ${ }^{*} P<0.05$, compared with the saline group; ${ }^{\#} P<0.05$, compared with the WT mBSA group. ${ }^{(-)}$deficient, AIA antigen-induced arthritis, i.a. intra-articular, $I L$ interleukin, $m B S A$ methylated bovine serum albumin, WT wild-type

compared with WT mice (Fig. 5b and c). The local production of IL-1 $\beta, \mathrm{KC} / \mathrm{CXCL}$ and MCP-1/CCL2, which were induced by i.a. administration of mBSA in WT immunized mice, was not altered in IL-1R1 ${ }^{-/-}$mice (Fig. 5d-f).

According to the hypothesis that IL-22 participates in the joint inflammatory response during AIA through the stimulation of IL-1 $\beta$ production, the injection of IL-22 into the joints of mBSA-immunized mice significantly increased the levels of IL-1 $\beta$ in a time-dependent manner (Fig. 6a). Moreover, the injection of exogenous rmIL-22 into the joints of $\mathrm{IL}-22^{-1-}$ mice reestablished the levels of IL- $1 \beta$ compared with the levels of WT mice during the mBSA challenge (Fig. 6b). In addition, joint hypernociception and neutrophil recruitment induced by i.a. injection of rmIL-22 were reduced in $\mathrm{IL}-1 \mathrm{R} 1^{-/-}$mice (Fig. $6 \mathrm{c}$ and d). Taken together, these data indicate that

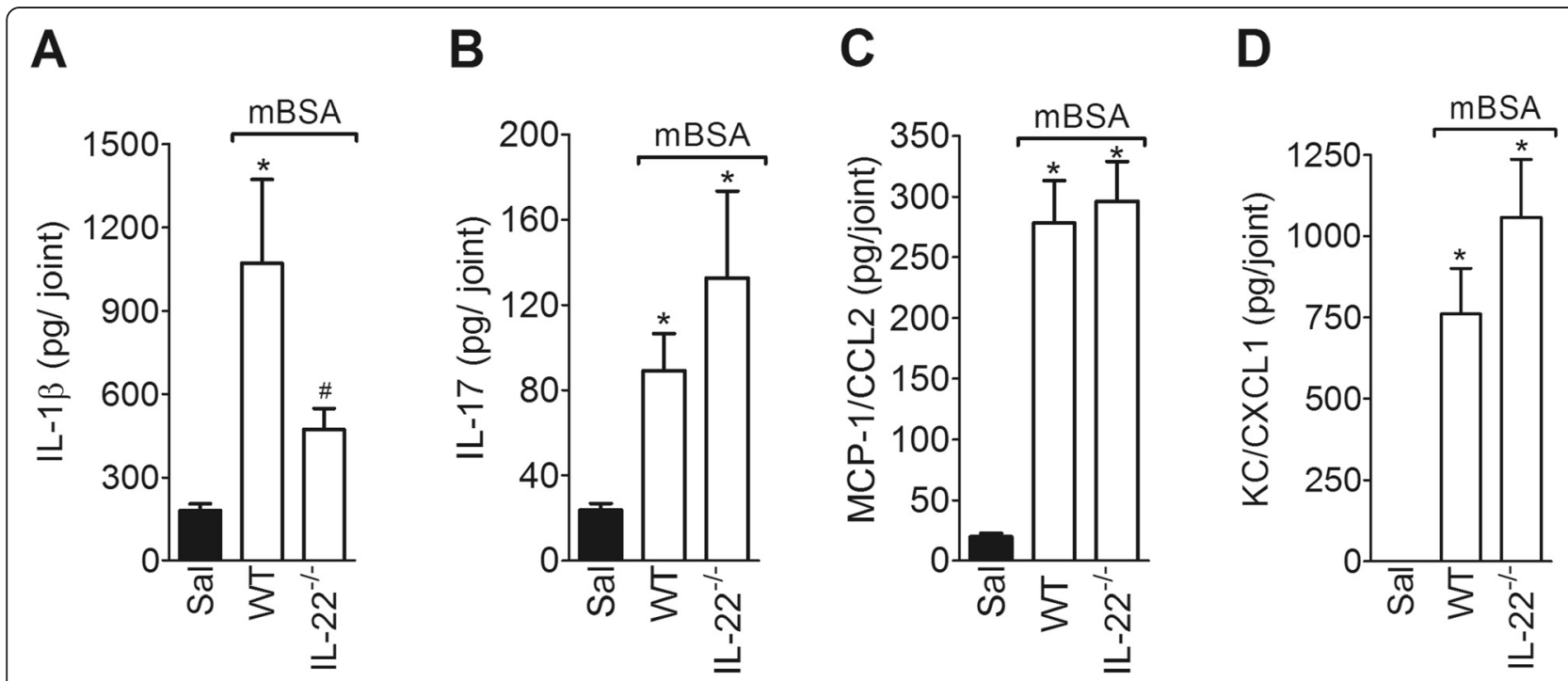

Fig. $4 \mathrm{IL}-22$ differentially regulates local pro-inflammatory cytokines and chemokines in the early phase of AIA. The concentrations of IL-1 $\beta$ (a), IL-17 (b), MCP-1/CCL2 (c) and KC/CXCL1 (d) in the knee joint injected with mBSA $(30 \mu \mathrm{g})$ or saline in WT and IL-22 ${ }^{-1-}$ mBSA-immunized mice were determined at $3 \mathrm{~h}$ after challenge. The levels of cytokines and chemokines were evaluated by ELISA. Data are the means \pm SEM $(n=5)$. ${ }^{*} P<0.05$, compared with the saline group; and ${ }^{\#} P<0.05$, compared with the mBSA group. ${ }^{(-)}{ }^{-1}$ deficient, AIA antigen-induced arthritis, ELISA enzyme-linked immunosorbent assay, IL interleukin, KC/CXCLI keratinocyte-derived chemokine, mBSA methylated bovine serum albumin, MCP-1/CCL2 monocyte chemoattractant protein-1, WT wild-type 


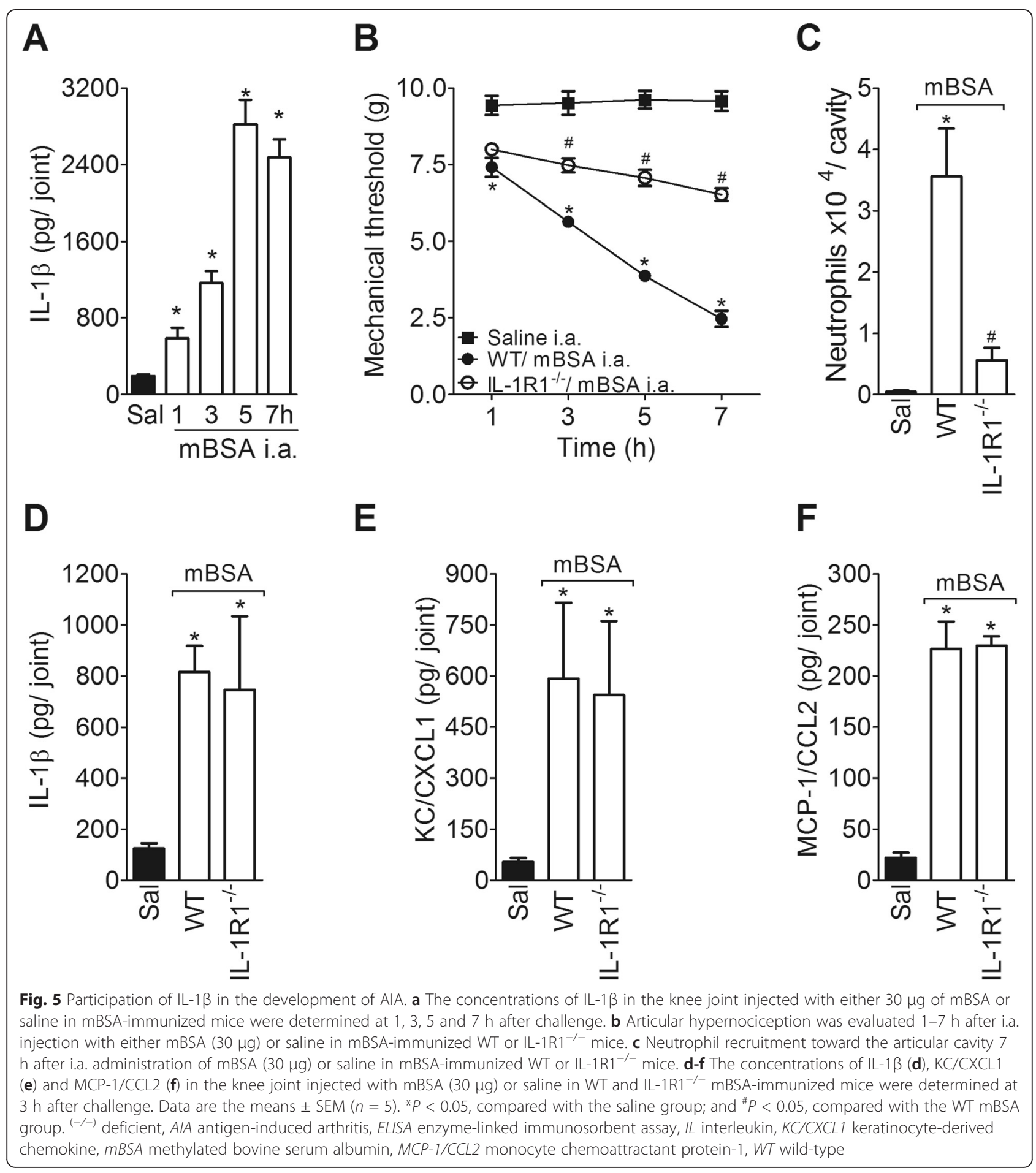

IL-22 might have a modulatory role in the production of IL- $1 \beta$ during the early phase of AIA that accounts for the local inflammatory response.

In an attempt to evaluate the mechanism involved in the production of IL- $1 \beta$ induced by IL- 22 during the acute phase of AIA, we first pretreated WT immunized mice with fucoidin (a leukocyte adhesion inhibitor) [32], and $3 \mathrm{~h}$ after a challenge with rmIL-22 (1 ng per joint), the levels of IL-1 $\beta$ were determined by ELISA. Interestingly, the joint production of IL- $1 \beta$ induced by IL- 22 was significantly increased in WT immunized mice pretreated with fucoidin when compared with the vehicle group (Figure S4A in Additional file 4), suggesting that neutrophils that are recruited to the joint after IL-22 administration are 


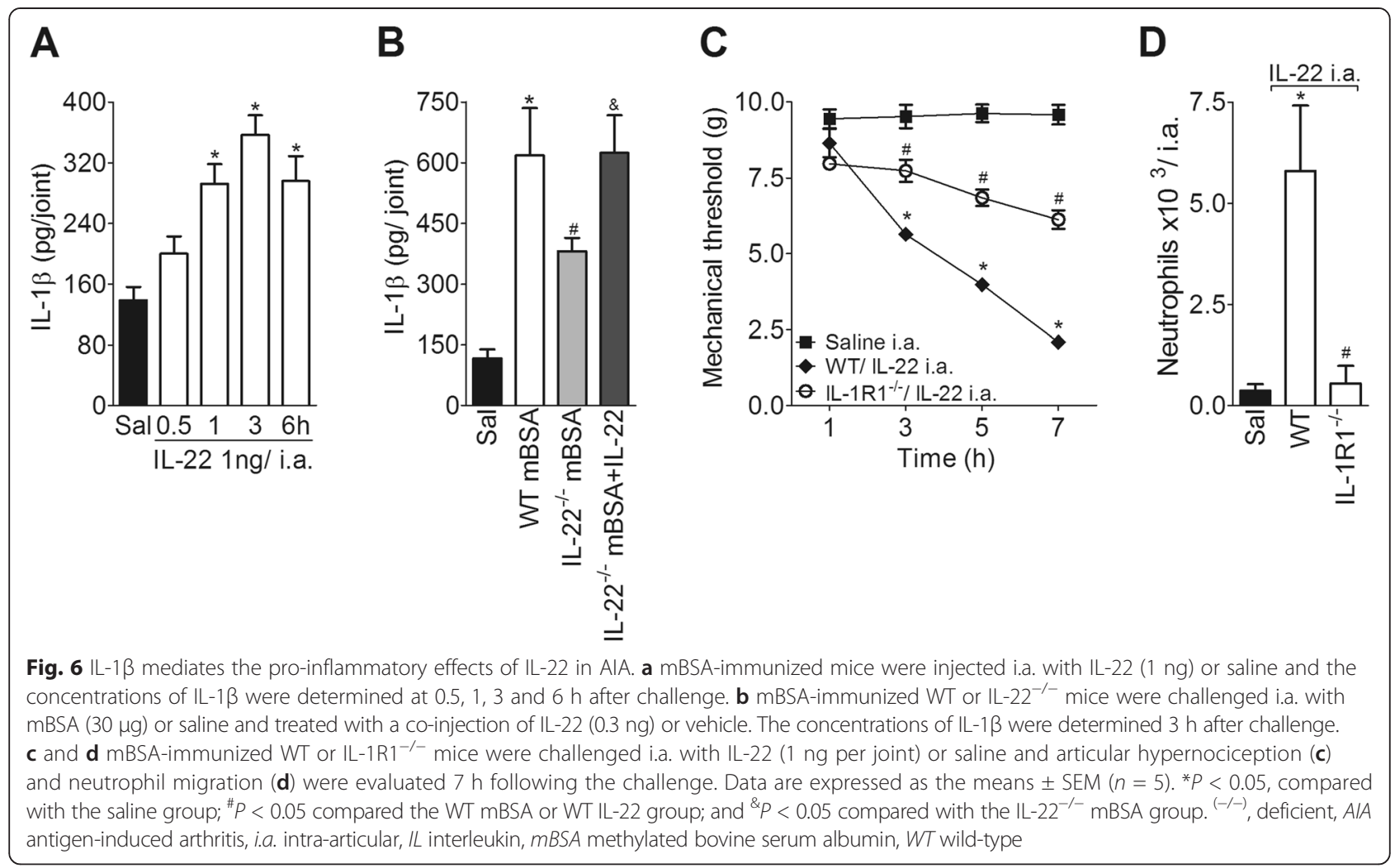

not the main source of IL-1 $\beta$. By further investigating the mechanisms involved in the production of IL- $1 \beta$ triggered by IL-22, it was observed that articular hypernociception and neutrophil migration induced by i.a. injections of IL-22 in WT immunized mice were significantly diminished in $\mathrm{ASC}^{-/-}$immunized mice $7 \mathrm{~h}$ after the challenge (Figure S4B and $C$ in Additional file 4). These results suggest (although indirectly) that IL-22 stimulation of joint IL-1 $\beta$ production in the acute phase of AIA might be dependent on ASC.

\section{Discussion}

It is well accepted that the presence of various proinflammatory cytokines in the joint environment contributes to the pathophysiology of autoimmune arthritis [33]. In the last decade, IL-22, a cytokine with pleiotropic effects, has been implicated in joint pathology during inflammatory arthritis [22, 23]. For instance, the presence of IL-22 and IL-22R1 in synovial tissue [22, 34] and elevated levels of this cytokine in the serum of RA patients have been demonstrated $[35,36]$. However, the role of IL-22 in the pathophysiology of RA remains under debate. In fact, experimental evidence presents contradictory effects (protective versus pathogenic) for IL-22 in the genesis of arthritis [26, 27, 37]. Herein, we demonstrated that IL-22 is pathogenic in the early phase of AIA in mice, mediating neutrophil migration and pain. IL-22 seems to be important in the induction of the local production of IL-1 $\beta$, which is an important pro-arthritic cytokine that mediates leukocyte recruitment to the joint as well as the joint pain.

Previous reports have observed an increase in IL-22 expression in experimental models of arthritis in mice. Indeed, Geboes and collaborators (2009) [26] first demonstrated that IL-22 and IL-22R1 levels were elevated in the serum, lymphoid tissue and others tissues in immunized mice during collagen-induced arthritis (CIA). In addition, in the experimental model of spontaneous arthritis observed in IL-1 receptor antagonist (Ra) ${ }^{-/-}$ mice, the level of IL-22 was shown to be upregulated in inflamed synovial tissue [38]. Moreover, $\mathrm{CD}^{+}{ }^{+} \mathrm{T}$ cells isolated from arthritic joints and splenocytes express IL-22 after the induction of AIA, suggesting the possible involvement of IL-22 in this model of arthritis [39, 40]. In further support of this suggestion, in our experiments, we observed that mRNA expression and protein levels of IL-22 in the synovial membrane increased during the onset of AIA. Moreover, the results obtained using pharmacological (antibody against IL-22) and genetic (IL-22 $2^{-/-}$mice) inhibition of this cytokine indicate a pro-inflammatory role of IL-22 in the earlier phase of AIA. Supporting these findings, the direct administration of recombinant murine IL-22 into the joints recapitulates the clinical (pain enhancement) and morphological (neutrophil migration) characteristics of arthritis. In agreement with our results, treatment with anti-IL-22 reduced inflammation and bone erosion in IL-1-driven arthritis 
[38]. Furthermore, neutralization of IL-22 after the onset of CIA diminished the severity of arthritis [37].

On the other hand, a recent report showed that IL-22 $2^{-/-}$ mice present no differences in knee swelling and macroscopic inflammation scores (evaluated by redness) compared to WT mice 7 days after AIA induction [41]. This lack of effect can be explained by the intense amount of stimuli (mBSA- $60 \mu \mathrm{g} / \mathrm{i} . \mathrm{a}$.) administered in the joint compared to that used in our study (mBSA- $30 \mu \mathrm{g} / \mathrm{i}$.a.). Furthermore, the time of evaluation of the parameters was also different. While we analyzed the role of IL-22 in the acute phase of AIA ( $7 \mathrm{~h}$ after induction), van Hamburg and colleagues (2013) evaluated the inflammatory parameters 7 days after AIA induction. Thus, we could not exclude that IL-22 might have a different role in acute and late phases of the disease. In fact, there is evidence that IL-22 has a dual role in inflammatory diseases [42, 43].

The experimental model of antigen (mBSA)-induced arthritis is a suitable and reproducible experimental system that exhibits several features with histopathological findings similar to those observed in human RA [28]. The adaptive immune response in AIA is dependent on antigen-specific $\mathrm{CD} 4^{+} \mathrm{T}$ cells and their derived mediators and, to a lesser extent, is mediated by serum antibodies $[44,45]$. Interestingly, the titers of anti-mBSA antibodies were similar in WT and IL-22 $2^{-/-}$mice. This is noteworthy, because IL-22 $2^{-1-}$ mice exhibit higher levels of collagen type II-specific and total IgG antibodies during CIA [26]. Although anti-mBSA antibodies have been detected in AIA, it is important to mention that this RA model is less dependent on the humoral response [28]. Indeed, B-lymphocyte-deficient $\mu \mathrm{MT} / \mu \mathrm{MT}$ mice (which lack mature B lymphocytes and do not produce IgM or IgG antibodies) develop AIA that is similar to that developed in WT mice, suggesting that B cells do not participate, at least during the acute phase of AIA [46]. Besides the humoral response, it was demonstrated that the proliferative response, $\mathrm{T}$ cell phenotype and cytokine levels in the supernatant of lymph node cells were similar between arthritic IL-22 ${ }^{-/-}$and WT mice [41]. Taken together, these pieces of evidence indicate that the lower inflammatory response of $\mathrm{IL}-22^{-/-}$mice during AIA was not associated with a decreased humoral or cellular immune response to mBSA.

Previous reports have shown that mBSA injection induces the production of several cytokines (IL-17, IL-1 $\beta$ ) and chemokines $(\mathrm{CXCL} 1 / \mathrm{KC})$ during antigen-induced inflammation $[9,29,47]$. Interestingly, our findings demonstrate that only IL- $1 \beta$ production was decreased by the genetic inhibition of IL-22, indicating that the pathogenic role of IL-22 during AIA onset could be mediated through IL-1 $\beta$. In accordance with our results, it was demonstrated that the increased IL-1 $\beta$ expression in synovial tissues during CIA was diminished in IL-22 $2^{-/-}$ mice [26]. In addition, in an experimental model of skin inflammation, the levels of IL-1 $\beta$ were decreased in IL-22 $2^{-/-}$mice [48]. Nevertheless, we cannot exclude the involvement of other mediators in this effect of IL-22 in the early phase of AIA.

The participation of IL-1 $\beta$ was also observed in other models of articular inflammation. In fact, it was shown that IL-1 $\beta$ mediates inflammation and dysfunction of the joint induced by the injection of monosodium urate (MSU) crystals into the knee in an experimental model of gout [49]. Additionally, in the spontaneous inflammatory arthritis model of $\mathrm{K} / \mathrm{BxN}$ T cell receptor-transgenic mice, IL-1 $\beta$ is absolutely necessary for joint inflammation [50]. Our results indicate that IL-1 $\beta$ mediates the induction of inflammatory events (neutrophil migration and pain) in AIA, which is not dependent on the modulation of the production of cytokines and chemokines. Thus, it is possible that the pro-inflammatory effects of IL- $1 \beta$ that are observed during AIA might be directly connected to pain induction as a consequence of the stimulation of the production of prostaglandins (which are important in the sensitization of primary nociceptive fibers) and on neutrophil migration, since it can modulate endothelial adhesion molecules [51-53]. In addition, it is important to note that IL-1 $\beta$ also has direct and indirect effects in the nociceptive neurons, inducing their sensitization and neutrophil migration $[8,54-56]$. In this context, our group demonstrated that IL-1 $\beta$ mediates neutrophil migration induced by several cytokines, including IL-17, during AIA [9]. In the present study, no difference in the production of IL-17A was observed between IL-22 $2^{-1-}$ and WT mice, suggesting that the pro-arthritic role of IL-22 appears to be independent of IL-17 release in the joint. It is important to propose that IL-17 can induce IL-22 or that these cytokines may act together to mediate the pathogenesis of AIA. For instance, the interdependence of IL-17 and IL-22 in other models of experimental arthritis has been suggested $[38,57]$. Furthermore, the correlation of IL-17 and IL-22 was also observed in patients with arthritis [34]. Interestingly, the synergistic effect of these cytokines has already been demonstrated in other models of inflammation. Indeed, in an experimental model of airway inflammation, it was suggested that IL-22 can act cooperatively with IL-17A, which contributes to the pathological role of IL-22 in the lung [42, 43].

Concerning the mechanism involved in the IL-22induced production of IL-1 $\beta$, our data indicate that it is not dependent on recruited neutrophils, but it may be dependent on resident cells. Another important observation is that the pro-inflammatory role of IL-22 in joint inflammation appears to be dependent on ASC. In accordance, it was demonstrated that the adapter molecule ASC mediates the pro-inflammatory response in AIA and production of IL-1 $\beta$ [58]. However, it appears that 
the role of ASC in AIA development does not require NLRP3/caspase-1 and NLRC4/caspase-1 inflammasomes [58]. Thus, further studies are necessary to elucidate the relationship between IL-22 and ASC in the development of AIA.

\section{Conclusions}

In summary, the present data provides evidence that joint IL-22 is pathogenic during the onset of antigeninduced arthritis in mice. Our findings also suggest that the pro-inflammatory role of IL-22 in the physiopathology of arthritis is dependent on the modulation of IL-1 $\beta$ production in the joint, which may be dependent on ASC. Therefore, it seems that IL-22 is a possible therapeutic target in the initial phase of RA, controlling the various symptoms present in arthritis.

\section{Additional files}

Additional file 1: Figure S1. Pro-inflammatory effects of IL-22 in TLR4 ${ }^{-/}$ mice are similar to WT mice. (A and B) WT or TLR4 ${ }^{-1-}$ mice were challenged i.a. with IL-22 (1 ng per joint) or saline, and articular hypernociception (A) and neutrophil migration (B) were evaluated $7 \mathrm{~h}$ after the challenge. Data are presented as the means $\pm \operatorname{SEM}(n=5) .{ }^{*} P<0.05$, compared with the saline group. (TIFF $1072 \mathrm{~kb}$ )

Additional file 2: Figure S2. Immunoglobulin production of WT and $\mathrm{IL}-22^{-1-}$ mice. Levels of total $\lg \mathrm{G}(\mathrm{A})$ and $\lg \mathrm{G} 2 \mathrm{a}(\mathrm{B})$ antibodies against $\mathrm{mBSA}$ in the sera of WT and $\mathrm{IL}-22^{-1-} \mathrm{mBSA}$-immunized mice. Data are the means \pm SEM $(n=5)$. (TIFF $1185 \mathrm{~kb})$

Additional file 3: Figure S3. Role of IL-22 in zymosan-induced arthritis. (A and B) WT or IL-22 $2^{-1-}$ mice were challenged i.a. with zymosan $(30 \mu \mathrm{g}$ per joint) or saline and articular hypernociception (A) and neutrophil migration (B) were evaluated $7 \mathrm{~h}$ after the challenge. Data are presented as the means \pm SEM $(n=5)$. ${ }^{*} P<0.05$, compared with the saline group. (TIFF $1105 \mathrm{~kb}$ )

Additional file 4: Figure S4. The inflammasome adapter ASC participates in articular hypernociception and neutrophil migration that are induced by $\mathrm{IL}-22$ during AIA. (A) The concentrations of $\mathrm{L}-1 \beta$ in the knee joint injected with $1 \mathrm{ng}$ of IL-22 or saline and pretreated with fucoidin ( $20 \mathrm{mg} / \mathrm{kg}$, i.v. 15 min before stimuli injection) in mBSA-immunized mice were determined $3 \mathrm{~h}$ after the challenge. (B) Articular hypernociception was evaluated 1-7 h after i.a. injection with either IL-22 (1 ng per joint) or saline in mBSA-immunized WT or $\mathrm{ASC}^{-1-}$ mice. (C) Neutrophil recruitment toward the articular cavity $7 \mathrm{~h}$ after i.a. administration of IL-22 (1 ng) or saline in mBSA-immunized WT or $\mathrm{ASC}^{-1-}$ mice. Data are presented as the means \pm SEM $(n=5)$. ${ }^{*} P<0.05$, compared with the saline group; and ${ }^{\#} P<0.05$, compared with the vehicle (-)/WT IL-22 groups. (TIFF $930 \mathrm{~kb}$ )

\footnotetext{
Abbreviations

${ }_{(-/)}$: deficient/knockout mice; AIA: antigen-induced arthritis; ASC: apoptosisassociated speck-like protein containing a C-terminal caspase recruitment domain; CFA: complete Freund adjuvant; CIA: collagen-induced arthritis; $C T$ : cycle threshold; CTL: control; EDTA: ethylenediaminetetraacetic acid; ELISA: enzyme-linked immunosorbent assay; g: grams;

GAPDH: glyceraldehyde 3-phosphate dehydrogenase; H\&E: hematoxylin and eosin; i.a.: intra-articular; Ig: immunoglobulin; IL: interleukin;

KC/CXCL1: keratinocyte-derived chemokine; LPS: lipopolysaccharide; LTi: lymphoid tissue inducer; mBSA: methylated bovine serum albumin; MCP-1/CCL2: monocyte chemoattractant protein-1; MMPs: matrix metalloproteinases; MSU: monosodium urate; NK: natural killer; PBS: phosphate-buffered saline; Ra: receptor antagonist; RA: rheumatoid arthritis; rmIL-22: recombinant murine IL-22; RT-PCR: reverse transcriptionpolymerase chain reaction; s.c.: subcutaneous; SI: sham-immunized;
}

Th: T helper; TLR4: Toll-like receptor 4; TNF: tumor necrosis factor; WT: wild-type; ZIA: zymosan-induced arthritis.

\section{Competing interests}

The authors declare that they have no competing interests.

\section{Authors' contributions}

LGP conceived and designed the study, planned and performed all the experiments, analyzed the data and drafted the manuscript. JT designed the study, planned the experiments, contributed to and performed several experiments and helped revise the manuscript. RSP designed the study, planned the experiments, contributed and performed several experiments and helped revise the manuscript. RFF performed and analyzed the PCR and helped revise the manuscript. BR, JCAF and SHF contributed to the study's conception and helped revise the manuscript. FF contributed with histological staining and analyses, and helped revise the manuscript. TMC and FQC also conceived and designed the study, supervised the study and drafted the manuscript. All authors read and approved the final manuscript.

\section{Acknowledgements}

We thank leda Regina dos Santos Schivo, Sérgio Roberto Rosa, Ana Kátia dos Santos and Giuliana Bertozi Francisco for their excellent technical assistance. This work was supported by grants from the European Union Seventh Framework Programme [FP7-2007-2013] under grant agreement number HEALTH-F4-2011-281608 (TIMER), from the São Paulo Research Foundation (FAPESP) under grant agreements number 2011/19670-0 (Projeto Temático) and 2013/08216-2 (Center for Research in Inflammatory Disease) and from the University of São Paulo NAP-DIN under grant agreement number 11.1.21625.01.0.

\section{Author details}

${ }^{1}$ Department of Pharmacology, Ribeirão Preto Medical School, University of São Paulo, Avenida Bandeirantes, 3900, Ribeirão Preto, São Paulo 14049-900, Brazil. ${ }^{2}$ Université d'Orléans and CNRS, UMR 7355 Molecular and Experimental Immunology and Neurogenetics, 3b rue de la Férollerie, 45071 Orléans, France. ${ }^{3}$ Laboratory of Pathology, School of Medicine, University of Brasilia, Campus Universitário Darcy Ribeiro, Brasilia 70910-900, Brazil. ${ }^{4}$ Present Address: Aggeu Magalhaes Research Center, Oswaldo Cruz Foundation FIOCRUZ, Avenida Profesor Moreaes Rego s/n, Recife 50740-465, Brazil.

Received: 15 January 2015 Accepted: 18 August 2015

Published online: 02 September 2015

\section{References}

1. Mclnnes IB, Schett G. The pathogenesis of rheumatoid arthritis. N Engl J Med. 2011;365:2205-19.

2. Mclnnes IB, Schett G. Cytokines in the pathogenesis of rheumatoid arthritis. Nat Rev Immunol. 2007;7:429-42.

3. Miossec P. An update on the cytokine network in rheumatoid arthritis. Curr Opin Rheumatol. 2004;16:218-22.

4. Arend WP, Dayer JM. Inhibition of the production and effects of interleukin-1 and tumor necrosis factor alpha in rheumatoid arthritis. Arthritis Rheum. 1995;38:151-60.

5. Brennan FM, McInnes IB. Evidence that cytokines play a role in rheumatoid arthritis. J Clin Invest. 2008;118:3537-45.

6. Boettger MK, Hensellek S, Richter F, Gajda M, Stöckigt R, von Banchet GS, et al. Antinociceptive effects of tumor necrosis factor alpha neutralization in a rat model of antigen-induced arthritis: evidence of a neuronal target. Arthritis Rheum. 2008;58:2368-78.

7. Brenn D, Richter F, Schaible HG. Sensitization of unmyelinated sensory fibers of the joint nerve to mechanical stimuli by interleukin- 6 in the rat: an inflammatory mechanism of joint pain. Arthritis Rheum. 2007;56:351-9.

8. Copray JC, Mantingh I, Brouwer N, Biber K, Küst BM, Liem RS, et al. Expression of interleukin-1 beta in rat dorsal root ganglia. J Neuroimmunol. 2001;118:203-11.

9. Pinto LG, Cunha TM, Vieira SM, Lemos HP, Verri WA, Cunha FQ, et al. IL-17 mediates articular hypernociception in antigen-induced arthritis in mice. Pain. 2010;148:247-56.

10. Richter F, Natura G, Ebbinghaus M, von Banchet GS, Hensellek S, König C, et al. Interleukin-17 sensitizes joint nociceptors to mechanical stimuli and contributes to arthritic pain through neuronal interleukin-17 receptors in rodents. Arthritis Rheum. 2012;64:4125-34. 
11. Ouyang W, Rutz S, Crellin NK, Valdez PA, Hymowitz SG. Regulation and functions of the IL-10 family of cytokines in inflammation and disease. Annu Rev Immunol. 2011;29:71-109.

12. Zenewicz LA, Flavell RA. Recent advances in IL-22 biology. Int Immunol. 2011;23:159-63.

13. Dumoutier L, Van Roost E, Colau D, Renauld JC. Human interleukin-10-related T cell-derived inducible factor: molecular cloning and functional characterization as an hepatocyte-stimulating factor. Proc Natl Acad Sci U S A. 2000;97:10144-9.

14. Kotenko SV, Izotova LS, Mirochnitchenko OV, Esterova E, Dickensheets H, Donnelly RP, et al. Identification of the functional interleukin-22 (IL-22) receptor complex: the IL-10R2 chain (IL-10Rbeta) is a common chain of both the IL-10 and IL-22 (IL-10-related T cell-derived inducible factor, IL-TIF) receptor complexes. J Biol Chem. 2001;276:2725-32.

15. Wolk K, Kunz S, Witte E, Friedrich M, Asadullah K, Sabat R. IL-22 increases the innate immunity of tissues. Immunity. 2004;21:241-54.

16. Xie MH, Aggarwal S, Ho WH, Foster J, Zhang Z, Stinson J, et al. Interleukin (IL)-22, a novel human cytokine that signals through the interferon receptor-related proteins CRF2-4 and IL-22R. J Biol Chem. 2000;275:31335-9.

17. Wolk K, Witte E, Witte K, Warszawska K, Sabat R. Biology of interleukin-22. Semin Immunopathol. 2010;32:17-31.

18. Aujla SJ, Kolls JK. IL-22: a critical mediator in mucosal host defense. J Mol Med (Berl). 2009;87:451-4.

19. Witte E, Witte K, Warszawska K, Sabat R, Wolk K. Interleukin-22: a cytokine produced by T, NK and NKT cell subsets, with importance in the innate immune defense and tissue protection. Cytokine Growth Factor Rev. 2010;21:365-79.

20. Wolk K, Witte E, Wallace E, Döcke WD, Kunz S, Asadullah K, et al. IL-22 regulates the expression of genes responsible for antimicrobial defense, cellular differentiation, and mobility in keratinocytes: a potential role in psoriasis. Eur J Immunol. 2006:36:1309-23.

21. Zheng Y, Danilenko DM, Valdez P, Kasman I, Eastham-Anderson J, Wu J, et al. Interleukin-22, a T(H)17 cytokine, mediates IL-23-induced dermal inflammation and acanthosis. Nature. 2007:445:648-51.

22. Ikeuchi H, Kuroiwa T, Hiramatsu N, Kaneko Y, Hiromura K, Ueki K, et al. Expression of interleukin-22 in rheumatoid arthritis: potential role as a proinflammatory cytokine. Arthritis Rheum. 2005;52:1037-46.

23. Leipe J, Schramm MA, Grunke M, Baeuerle M, Dechant C, Nigg AP, et al. Interleukin 22 serum levels are associated with radiographic progression in rheumatoid arthritis. Ann Rheum Dis. 2011;70:1453-7.

24. da Rocha LF, Duarte Â, Dantas AT, Mariz HA, Pitta Ida R, Galdino SL, et al. Increased serum interleukin 22 in patients with rheumatoid arthritis and correlation with disease activity. J Rheumatol. 2012;39:1320-5.

25. Zhang L, Li JM, Liu XG, Ma DX, Hu NW, Li YG, et al. Elevated Th22 cells correlated with Th17 cells in patients with rheumatoid arthritis. J Clin Immunol. 2011;31:606-14.

26. Geboes L, Dumoutier L, Kelchtermans H, Schurgers E, Mitera T, Renauld JC, et al. Proinflammatory role of the Th17 cytokine interleukin-22 in collageninduced arthritis in C57BL/6 mice. Arthritis Rheum. 2009;60:390-5.

27. Sarkar S, Zhou X, Justa S, Bommireddy SR. Interleukin-22 reduces the severity of collagen-induced arthritis in association with increased levels of interleukin-10. Arthritis Rheum. 2013;65:960-71.

28. Brackertz D, Mitchell GF, Mackay IR. Antigen-induced arthritis in mice. I. Induction of arthritis in various strains of mice. Arthritis Rheum. 1977;20:841-50.

29. Verri WA, Guerrero AT, Fukada SY, Valerio DA, Cunha TM, Xu D, et al. IL-33 mediates antigen-induced cutaneous and articular hypernociception in mice. Proc Natl Acad Sci U S A. 2008;105:2723-8.

30. Rocha FA, Leite AK, Pompeu MM, Cunha TM, Verri WA, Soares FM, et al. Protective effect of an extract from Ascaris suum in experimental arthritis models. Infect Immun. 2008;76:2736-45.

31. Grespan R, Fukada SY, Lemos HP, Vieira SM, Napimoga MH, Teixeira MM, et al. CXCR2-specific chemokines mediate leukotriene B4-dependent recruitment of neutrophils to inflamed joints in mice with antigen-induced arthritis. Arthritis Rheum. 2008;58:2030-40.

32. Ley K, Linnemann G, Meinen M, Stoolman LM, Gaehtgens P. Fucoidin, but not yeast polyphosphomannan PPME, inhibits leukocyte rolling in venules of the rat mesentery. Blood. 1993:81:177-85.

33. Burmester GR, Feist E, Dörner T. Emerging cell and cytokine targets in rheumatoid arthritis. Nat Rev Rheumatol. 2014;10:77-88.

34. Carrión M, Juarranz Y, Martínez C, González-Álvaro I, Pablos JL, Gutiérrez-Cañas I, et al. IL-22/LL-22R1 axis and S100A8/A9 alarmins in human osteoarthritic and rheumatoid arthritis synovial fibroblasts. Rheumatology (Oxford). 2013;52:2177-86.
35. Kim KW, Kim HR, Park JY, Park JS, Oh HJ, Woo YJ, et al. Interleukin-22 promotes osteoclastogenesis in rheumatoid arthritis through induction of RANKL in human synovial fibroblasts. Arthritis Rheum. 2012;64:1015-23.

36. Zhao $L$, Jiang $Z$, Jiang $Y$, Ma N, Zhang $Y$, Feng $L$, et al. IL-22+ CD4+ T cells in patients with rheumatoid arthritis. Int J Rheum Dis. 2013;16:518-26.

37. Justa S, Zhou X, Sarkar S. Endogenous IL-22 plays a dual role in arthritis: regulation of established arthritis via IFN- $\gamma$ responses. PLoS One. 2014;9, e93279.

38. Marijnissen RJ, Koenders MI, Smeets RL, Stappers MH, Nickerson-Nutter C, Joosten LA, et al. Increased expression of interleukin-22 by synovial Th17 cells during late stages of murine experimental arthritis is controlled by interleukin-1 and enhances bone degradation. Arthritis Rheum. 2011;63:2939-48.

39. Cornelissen F, Mus AM, Asmawidjaja PS, van Hamburg JP, Tocker J, Lubberts E. Interleukin-23 is critical for full-blown expression of a non-autoimmune destructive arthritis and regulates interleukin-17A and RORgammat in gammadelta T cells. Arthritis Res Ther. 2009;11:R194.

40. van Hamburg JP, Mus AM, de Bruijn MJ, de Vogel L, Boon L, Cornelissen F, et al. GATA-3 protects against severe joint inflammation and bone erosion and reduces differentiation of Th17 cells during experimental arthritis. Arthritis Rheum. 2009;60:750-9.

41. van Hamburg JP, Corneth OB, Paulissen SM, Davelaar N, Asmawidjaja PS, Mus AM, et al. IL-17/Th17 mediated synovial inflammation is IL-22 independent. Ann Rheum Dis. 2013;72:1700-7.

42. Besnard AG, Sabat R, Dumoutier L, Renauld JC, Willart M, Lambrecht B, et al. Dual Role of IL-22 in allergic airway inflammation and its cross-talk with IL-17A. Am J Respir Crit Care Med. 2011;183:1153-63.

43. Sonnenberg GF, Nair MG, Kirn TJ, Zaph C, Fouser LA, Artis D. Pathological versus protective functions of $\mathrm{IL}-22$ in airway inflammation are regulated by IL-17A. J Exp Med. 2010;207:1293-305.

44. Petrow PK, Thoss K, Katenkamp D, Bräuer R. Adoptive transfer of susceptibility to antigen-induced arthritis into severe combined immunodeficient (SCID) mice: role of CD4+ and CD8+ T cells. Immunol Invest. 1996;25:341-53.

45. Pohlers D, Nissler K, Frey O, Simon J, Petrow PK, Kinne RW, et al. Anti-CD4 monoclonal antibody treatment in acute and early chronic antigeninduced arthritis: influence on T helper cell activation. Clin Exp Immunol. 2004;135:409-15.

46. Wong PK, Quinn JM, Sims NA, van Nieuwenhuijze A, Campbell IK, Wicks IP. Interleukin-6 modulates production of T lymphocyte-derived cytokines in antigen-induced arthritis and drives inflammation-induced osteoclastogenesis. Arthritis Rheum. 2006;54:158-68.

47. Cunha TM, Verri WA, Valério DA, Guerrero AT, Nogueira LG, Vieira SM, et al. Role of cytokines in mediating mechanical hypernociception in a model of delayed-type hypersensitivity in mice. Eur J Pain. 2008;12:1059-68.

48. Ma HL, Liang S, Li J, Napierata L, Brown T, Benoit S, et al. IL-22 is required for Th17 cell-mediated pathology in a mouse model of psoriasis-like skin inflammation. J Clin Invest. 2008;118:597-607.

49. Amaral FA, Costa W, Tavares LD, Sachs D, Coelho FM, Fagundes CT, et al. NLRP3 inflammasome-mediated neutrophil recruitment and hypernociception depend on leukotriene B(4) in a murine model of gout. Arthritis Rheum. 2012;64:474-84.

50. Ji H, Pettit A, Ohmura K, Ortiz-Lopez A, Duchatelle V, Degott C, et al. Critical roles for interleukin 1 and tumor necrosis factor alpha in antibody-induced arthritis. J Exp Med. 2002;196:77-85.

51. Angel J, Berenbaum F, Le Denmat C, Nevalainen T, Masliah J, Fournier C. Interleukin-1-induced prostaglandin E2 biosynthesis in human synovial cells involves the activation of cytosolic phospholipase A2 and cyclooxygenase-2. Eur J Biochem. 1994;226:125-31.

52. Cunha TM, Verri WA, Schivo IR, Napimoga MH, Parada CA, Poole S, et al. Crucial role of neutrophils in the development of mechanical inflammatory hypernociception. J Leukoc Biol. 2008;83:824-32.

53. Jorgensen C, Angel J, Fournier C. Regulation of synovial cell proliferation and prostaglandin E2 production by combined action of cytokines. Eur Cytokine Netw. 1991:2:207-15.

54. Binshtok AM, Wang H, Zimmermann K, Amaya F, Vardeh D, Shi L, et al. Nociceptors are interleukin-1beta sensors. J Neurosci. 2008;28:14062-73.

55. Cunha TM, Verri WA, Silva JS, Poole S, Cunha FQ, Ferreira SH. A cascade of cytokines mediates mechanical inflammatory hypernociception in mice. Proc Natl Acad Sci U S A. 2005;102:1755-60.

56. Ferreira SH, Lorenzetti BB, Bristow AF, Poole S. Interleukin-1 beta as a potent hyperalgesic agent antagonized by a tripeptide analogue. Nature. 1988;334:698-700 
57. Pineda MA, Rodgers DT, Al-Riyami L, Harnett W, Harnett MM. ES-62 protects against collagen-induced arthritis by resetting interleukin-22 toward resolution of inflammation in the joints. Arthritis Rheumatol. 2014;66:1492-503.

58. Kolly L, Karababa M, Joosten LA, Narayan S, Salvi R, Pétrilli V, et al. Inflammatory role of ASC in antigen-induced arthritis is independent of caspase-1, NALP-3, and IPAF. J Immunol. 2009;183:4003-12.

Submit your next manuscript to BioMed Central and take full advantage of:

- Convenient online submission

- Thorough peer review

- No space constraints or color figure charges

- Immediate publication on acceptance

- Inclusion in PubMed, CAS, Scopus and Google Scholar

- Research which is freely available for redistribution 